\title{
Work Life Balance of Women Employees, with Reference to Amtex Software Solutions Chennai
}

\author{
Magdalene Peter, S.Fabiyola Kavitha
}

\begin{abstract}
Ladies are superior to anything men with regards to valuing their association's endeavors in guaranteeing a superior work-life balance for their representatives. Ladies are progressively turning into a piece of the dynamic workforce and are taking care of work effectively as well as are additionally running their homes in a praiseworthy way. In each conventional Indian family, ladies are instructed from youth itself that they will deal with family duties when they grow up. The childhood additionally causes them find out about overseeing things in a superior way. What's more, with current instruction and openings, ladies have really turned out to be fit for dealing with all that and significantly more. This presentation and experience improves them chiefs at work as well. Ladies are genuinely and rationally more grounded than men. This causes them handle weight and worry in a superior way and with more noteworthy spryness. In addition, it additionally encourages them stand firm notwithstanding afflictions and this is actually what gives them an edge. [1],[ 3],[5]
\end{abstract}

There are numerous ladies, who at the pinnacle of their vocations, quit their business to deal with their families or youngsters and joined the workforce again when things had settled. These ladies are nearly as effective as men who began their profession simultaneously. Here we ought to comprehend the significance of the term work-life balance and guarantee that each individual can have a harmony between their work and family life. [2 ],[ 4],[6]

People don't have only one drive, however numerous drives and needs and to have a feeling of prosperity, these requirements should be met satisfactorily. Work is significant as it gives a great deal of importance throughout everyday life, except life is greater than work. At the point when our lives are just about work, the capacity to address different issues goes exceptionally low which results in disappointment. Prosperity and certainty leaves. uncovering of PDA incorporation in effects on police reports.

Keywords : Work Life, Women, Barriers

\section{INTRODUCTION}

The structure of the present workforce is substantially more mind boggling. Double salary families and single guardians with wards are the standard. Our lives are ending up progressively complex as time passes.

Revised Manuscript Received on July 22, 2019.

Magdalene Peter, Department of MBA, Bharath Institute of Higher Education and Research, Tamilnadu, India. Email: magdalene.bsb@gmail.com

Dr.S.Fabiyola Kavitha, Department of MBA, Bharath Institute of Higher Education and Research, Tamilnadu, India. Email: fabiyolakavitha@gmail.com
The substance of the work environment has changed significantly as we head into the 21 st century. This, together with gigantic jumps in innovation, expanded challenge, and globalization has made another work environment reality, which looks to some extent like the work request of the past.

The workforce is experiencing issues adjusting work-life exercises. While one individual bore the weight before, the obligations are regularly shared between two working people today. Both feel the strain to adjust work and family life - and crush in some time for themselves.

In ventures, where the work market is focused or aptitudes are rare, offering representatives benefits that stretch out past essential statutory necessities can enable an organization to stand out from the group. Albeit in all respects somewhat contacted in class, work-life equalization is seen as a key part of the bundle offered to the representatives, as in the working environment of things to come, numerous businesses are understanding that the main consistent upper hand they will have is their kin - their scholarly capital. Hierarchical achievement relies upon individuals. Individuals have various obligations, assorted requirements, and frequently, clashing needs. Driving associations need to draw in and hold the best individuals. Individuals need work encounters where they can arrive at their maximum capacity, be completely drawn in, and have the option to meet their own and expert objectives and targets. [7],[9],[11]

This marvel of the too-persevering female is the same old thing; examines demonstrate that ladies will work any longer hours, and any working lady will reveal to you that they believe they need to take every necessary step or else it won't complete. [8],[ 10],[12]

In the event that the work-life parity isn't kept up, an individual can start to encounter a feeling of void and emptiness which is hard to manage. What's more, connections endure and the individual starts to encounter forlornness, misery, depression and criticism. [13], [15] ,[ 17]

Because of statistic and cultural changes, globalization and advances in innovation it is constraining business to change the manner in which they work. Work-life balance techniques are a significant apparatus in this change. They offer a success win circumstance, drawing in workers on the premise that there is 'something in it for them' as

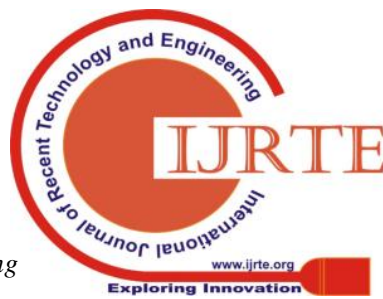


well, and adapting the procedure of progress.

Ladies more often than not hold up under the brunt. Leaving ahead of schedule from their homes and returning home late during the evening.

Steady weight at work with long moves makes it troublesome in keeping up a decent positive family environment at home. They don't have satisfactory time to go through with their family. [14],[ 16], [18]

The circumstance is distinctive in different nations, for example, US or UK where the administration makes it required for the organizations to set up work-life balance activities. In a to a great extent male ruled society in India, ladies for the most part get the worst part of the deal. Numerous Indian associations aren't doing much about it and this needs to change. They don't take a gander at it as a need. Innovation can be accused also. With quick progression of innovation, we are associated like never before. With different contraptions, for example, workstations, PDAs, palm tops and so forth, we have simple access to data and can be associated constantly. And yet, we are bringing our work home and it is attacking our lives.

An adaptable workplace and work-life equalization are the key drivers of worker fulfillment.

\section{RESEARCH METHODOLOGY}

Research in like manner speech alludes to a quest for learning. Once can likewise characterize investigate as a logical and orderly quest for relevant data on a particular theme. Indeed, examine is a specialty of logical examination. The Advanced Learner's Dictionary of Current English sets out the significance of research as "a cautious examination or request uniquely through quest for new actualities in any part of information." Redman and Mory characterize inquire about as a "systematized exertion to increase new information." Some individuals think about research as a development, a development from the known to the obscure. It is really a voyage of revelation. We as a whole have the indispensable nature of curiosity for, when the obscure stands up to us, we wonder and our curiosity makes us test and accomplish full and more full comprehension of the obscure. This curiosity is the mother of all information and the technique, which man utilizes for acquiring the learning of whatever the obscure, can be named as research. [25],[27],[29]

Research is a scholarly action and accordingly the term ought to be utilized in a specialized sense. As per Clifford Woody research contains characterizing and rethinking issues, planning speculation or proposed arrangements; gathering, sorting out and assessing information; making findings and arriving at resolutions; and finally cautiously testing the ends to decide if they fit the defining theory. D. Slesinger and M. Stephenson in the Encyclopedia of Social Sciences characterize examine as "the control of things, ideas or images to sum up to broaden, right or confirm learning, regardless of whether that information helps in development of hypothesis or in the act of a workmanship." [26],[28],[30]

Research is, in this way, a unique commitment to the current load of information making for its progression. It is the persuit of truth with the assistance of study, perception, examination and analysis. To put it plainly, the quest for information through target and efficient technique for discovering answer for an issue is inquire about. The efficient methodology concerning speculation and the plan of a hypothesis is likewise examine. In that capacity the term 'look into' alludes to the deliberate strategy comprising of articulating the issue, detailing a speculation, gathering the certainties or information, dissecting the realities and arriving at specific resolutions either as solutions(s) towards the concerned issue or in specific speculations for some hypothetical plan. [19],[21],[23]

\section{OBJECTIVE OF THE STUDY}

\section{A. Primary Objective}

- To discover the work life equalization of ladies representatives and how it influences their presentation at work with reference to Amtex Software Solutons Pvt. Ltd.

\section{B. Secondary Objectives}

- To study the stressors that influences the ladies representatives.

- To dissect work-life parity issues and their effect on Family.

- To learn about time the executives and its significance in a healthy lifestyle.

\section{IV.RESEARCH DESIGN}

An examination configuration is the game plan of conditions for accumulation and investigation of information in way that expects to consolidate importance to the exploration reason with economy by strategy, the examination, structure points of interest the strategies for information gathering, testing plan information investigation and elucidation. The exploration has taken the elucidating research. Clear research means depicting the condition of nature of certainties as it at present time. [20], [ 22], [24]

\section{A.Research area}

The area of study covers Amtex Software Solutions Pvt Ltd, Chennai.

\section{B.Research unit}

Women Employees of Amtex Software Solutions Pvt

Ltd, Chennai 


\section{C.Research period}

One month.

\section{D.Sample population:}

Sample population is 200 employees.

The sample size is taken as $\mathbf{1 2 0 .}$

E.Sample Break up: Employees belonging to the IT sector of ASI - 85

\section{Employees belonging to the ITES sector of ASI 35}

This break up has been so arrived to focus more on the women employees of the IT sector. This is because the unique aspect of the IT sector with it's flexible work policies, etc. Even with the policies in place, women employees still fact the problem of balancing their work and family life. [31],[33],[32]

\section{DATA \\ ANALYSIS \\ INTERPRETATION}

AND

\section{Simple Percentage Analysis}

Table 1 The hours of work in a week are too much for me

\begin{tabular}{|l|l|l|}
\hline S.No. & Particulars & No of respondents \\
\hline 1. & Strongly Agree & 9 \\
\hline 2. & Agree & 72 \\
\hline 3. & Neither agree or disagree & 12 \\
\hline 4. & Disagree & 6 \\
\hline 5. & Strongly Disagree & 1 \\
\hline & Total & 100 \\
\hline
\end{tabular}

m Strongly Agree $\|$ Agree $\|$ Neither agree or disagree $\boldsymbol{m}$ Disagree $\|$ Strongly Disagree

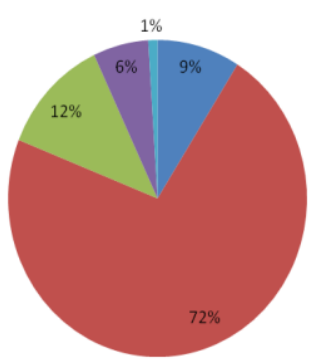

Fig:1 The hours of work in a week are too much for me

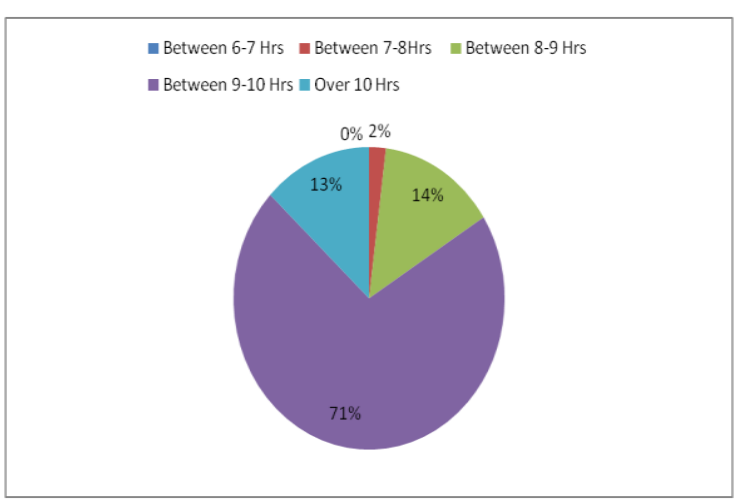

Fig:2 Number of hours in a day do you normally work

Alternative Hypothesis (H1):There is a significant relationship between the Importance of balancing work and family and Respondents feeling Tired or Depressed at work

Table:2

1. Percentage Analysis 2. Chi - squa

\begin{tabular}{|c|c|c|c|c|c|c|}
\hline Importance & \multirow{2}{*}{\begin{tabular}{|l|} 
Not \\
important
\end{tabular}} & \multirow[t]{2}{*}{ Important } & \multirow{2}{*}{$\begin{array}{l}\text { Neither } \\
\text { important }\end{array}$} & \multirow{2}{*}{$\begin{array}{l}\text { Of little } \\
\text { importance }\end{array}$} & \multirow{2}{*}{$\begin{array}{l}\text { Very } \\
\text { important }\end{array}$} & \multirow[t]{2}{*}{ Total } \\
\hline Tired or & & & & & & \\
\hline Never & 0 & 1 & 9 & 8 & 10 & 28 \\
\hline Rarely & 5 & 4 & 5 & 6 & 6 & 26 \\
\hline Sometimes & 6 & 5 & 6 & 7 & 8 & 32 \\
\hline Often & 4 & 2 & 3 & 1 & 1 & 11 \\
\hline Always & 1 & 1 & 1 & 0 & 0 & 3 \\
\hline Total & 16 & 13 & 24 & 22 & 25 & 100 \\
\hline
\end{tabular}

Table:3

\begin{tabular}{|l|l|l|l|l|}
\hline $\mathbf{O}$ & $\mathbf{E}$ & $\mathbf{O}-\mathbf{E}$ & $(\mathbf{O}-\mathbf{E})^{2}$ & $\frac{(\mathbf{O}-\mathbf{E})^{2}}{\mathbf{E}}$ \\
\hline 0 & & & & 4.47 \\
\hline 1 & 4.48 & -4.48 & 20.07 & 1.83 \\
\hline 9 & 3.64 & -2.64 & 6.96 & 0.77 \\
\hline 8 & 6.72 & 2.28 & 5.19 & 0.54 \\
\hline 10 & 6.16 & 1.84 & 3.38 & 1.28 \\
\hline 5 & 7 & 3 & 9 & 0.16 \\
\hline 4 & 4.16 & 0.84 & 0.70 & 0.11 \\
\hline 5 & 3.38 & 0.62 & 0.38 & 0.24 \\
\hline 6 & 6.24 & -1.24 & 1.53 & 0.01 \\
\hline 6 & 5.72 & 0.28 & 0.07 & 0.03 \\
\hline 6 & 6.5 & -0.5 & 0.25 & 0.24 \\
\hline 5 & 5.12 & 0.88 & 0.77 & 0.16 \\
\hline 6 & 4.16 & 0.84 & 0.70 & 0.36 \\
\hline
\end{tabular}

\section{V.RESULTS}

- We can see that a lion's share of the respondents feel that they invest an excessive amount of energy at work each week. This can be because of different reasons, for example, extra time work

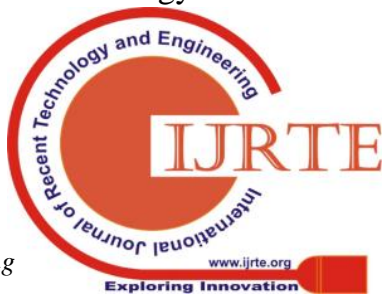


which will be talked about in the accompanying pie graphs to come.

- A greater part of the ladies representatives labor for 9-10 hours $(71 \%)$. This is comprehended on the grounds that the vast majority of the organizations hold fast to the standard of 8 hours of work multi day. This additional with the interims of break in the middle of results in the representatives spending at least 9 hours at the work environment consistently.

- We can see that most of the respondents accept that on the off chance that you experience issues at work and in your family can affect your exhibition at work and furthermore your work fulfillment. In the event that the work spot and family life requests are high, at that point the doubtlessly result will be that the worker will be influenced at work and furthermore, the representative won't be fulfilled regardless of the work done.

- Many of the respondents (93\%) can deal with their work and family so it doesn't adversely influence their exhibition at work. The $7 \%$ who are not ready to, are likely because of inappropriate organization strategies for work life balance, or have some unanticipated issues in the family, for example, being a solitary parent, divorced person and so forth.

- Majority of the respondent can't free their brains of their work and frequently think about the current task notwithstanding when they are not in the workplace or when they are voyaging. This can be because of overwhelming outstanding task at hand, and powerlessness of the worker to finish their objectives.

- We can see that a dominant part of the respondents don't feel that they are secured by the things that they do at home. They can deal with their time at home well and it doesn't influence the presentation at work. They may invest sufficient energy at home with their family and companions. There are some who are glad to invest more energy with their family.

- A dominant part of the respondents (90\%) felt that adaptable working hours were the most ideal approach to assist in adjusting work life at work and at home. With adaptable working hours, the representatives had the upside of getting down to business at the time that they saw fit. They had sufficient energy to deal with the work at home and afterward go to the workplace at whatever point required. A decent number of IT organizations now-a-days have the choice of adaptable working hours which permits representatives somewhat more opportunity to deal with their work life balance.

- The dominant part (100\%) of the respondents consistently picked work over family. This demonstrates the worry from their work and not the family truly influences them
- We can see that most respondents (58\%) don't feel the weight of work and just once in a while feel tired because of work. $38 \%$ of them feel that they are worn out from the work once in a while and $10 \%$ of them are frequently or constantly drained and discouraged because of the work. This is a major issue and ought to be tended to deliberately. The HR's job is to think about the issues looked by such representatives and guarantee that they have a legitimate work life balance.

- Most of the respondents were not thinking about any more youthful kin as they had their family to deal with them. Just 13 were dealing with more youthful kin or their own youngsters. Of the 13, the normal number of kin or youngsters taken consideration by them was 2 .

- This demonstrates that a dominant part by and large spends at least at any rate 4 hours with their family back home.

- We can see that $73 \%$ of the respondents said that they don't take extraordinary consideration for their folks or any seniors in their family and $27 \%$ said that they did. Their folks or older folks could be cared for by their relatives.

- We can see that a lion's share of the respondents feel that move work that always shows signs of change and long working hours beat the rundown on things that influences their work just as their family responsibilities. Meeting and preparing after available time were next with long working hours which were essentially extra time obligation because of different reasons, for example, venture culmination.

- We can see that lone two percent of the respondents really work at home. Most of them (98\%) don't telecommute, or carry their work to their homes. Of the 2 percent who do work at home, forty five minutes is the normal measure of time that they spend working from their homes.

- We can see that the quantity of respondents picking either alternatives are nearly the equivalent. This demonstrates there are right around an equivalent number of representatives who consider their work as opposed to concentrating on their home or other delight exercises, for example, excitement.

- We can see from the outline that $95 \%$ of the respondents acknowledge that they have surrendered their exercises or side interests that they appreciate for their work reason. The real imperative or reason would be absence of time, or them simply being worn out following a days work to really make the most of their leisure activities.

- Here, I might want to feature the significance of sexual orientation inclination. Ladies will for the most part feel that they don't invest enough energy with their friends and family while men as less 
inclined to be influenced by extended periods of time away from their family and companions at work.

- We can see from the chart that $69 \%$ of the respondents feel that they don't invest satisfactory energy with their friends and family as much as they preferred.

- $31 \%$ of the respondents felt that they invested satisfactory energy with their friends and family.

- We can see that the issue of adjusting work and family is given extensive significance by the greater part of the respondents (75\%). At the point when there is no harmony among family and work life, at that point it begins to worry the representatives, which thusly influences their exhibition at work, and furthermore their association with their relatives become stressed.

- The consistent reaction for the last inquiry demonstrates the significance of work life balance among representatives. All respondents felt that with work-life balance, not exclusively will representatives be glad, yet the associations wherein they work will turn out to be increasingly powerful and fruitful because of the way that workers will be better roused to work and perform over their typical benchmarks.

\section{DISCUSSION}

- Flexi-timings

Flexible timing were the number one choice of the respondents. They believed that flexible work timings will greatly help them manage their work and family life and help them achieve work life balance.

- Job sharing

Job sharing is an employment arrangement where typically two people are retained on a part-time or reduced-time basis to perform a job normally fulfilled by one person working full-time. Compensation is apportioned between the workers, thus leading to a net reduction in per-employee income.

\section{- Work timings}

The work timings of the employees need to be adjusted in such a way that it does not affect the time spent with their family. All human beings are social animals and need to spend time with their loved ones.

- Leave plans - both paid and unpaid - to suit employee's needs

There should be proper leave policies that are well defined. If we observe the leave policies of companies, the leaves allowed annually will be restricted to the job position. That is, higher ups will be allowed more leaves than the subordinates. This should not be allowed and everyone should be adequately compensated with paid leaves.

- Counseling services for problems like managing work and home - food preparation services, etc.

For those employees need the extra experience for managing their housework, special counseling can be conducted to show them how to effectively manage their housework without getting burned out.
- Jobs with autonomy and flexibility. The job should be flexible enough for employees so that they do not feel the work load pushing down on them. To avoid this, there should be adequate breaks in between.

- Realistic work loads

We must understand the every human being is different in their capability to do work. But at the same time, we should be realistic with the amount of work that we give to our employees.

.There should be programs conducted such as stress busters and counseling for all women employees.

- Access to childcare

Improving access to childcare with onsite childcare facilities and giving shift workers, who need access to childcare facilities, regular fixed shifts.

- Subsidized and proper food plans.

This is necessary especially in the IT and ITES environment where the pressures of work and the excess load that the employees have prevents them from having proper meals. This could lead to dietary and health problems at an early age. Women are more susceptible to diseases like osteoporosis in their later years if they do not follow a proper diet. The company should provide adequate, nutritious meals at a subsidized rate

\section{CONCLUSION}

Through this undertaking we can come to comprehend the significance of work life equalization and how every individual needs balance in his or her life. This is applicable in this regularly evolving condition. Ladies are engaged today. Gone are the days when they remained at home after marriage and dealt with their homes. The two life partners are attempting to get a salary and scarcely possess energy for whatever else separated from work. This sort of way of life will in the end lead to a breakdown both rationally and physically.

The connection among individual and expert life can be rough and keeping up the work life equalization is regularly a dubious issue. It is important to give equivalent significance to both work and family life. Associations ought to consistently point in presenting work-family balance strategies. A representative who is fulfilled and content with his work and family are the ones who will perform superior to the normal laborer. There are times when one would feel that their work life is attacking into their private time with their family. What's more, there are times when the remaining task at hand can turn out to be a lot to deal with. Be that as it may, we should attempt to keep up an appropriate harmony in both. This can be accomplished by taking a gander at where we presently stand and where we might want to go. Whatever difficulties that may come, we should stand up and face them.

\section{REFERENCES}

1. G BharthVajan R., Ramachandran S.,Psychographic dimensions of training,2016,International Journal of Pharmacy and 
Technology,V-8,I-4,P-23727-23729

2. Balakrishnan P., Bharthvajan R.,A study on human resource planning in hospitals in Chennai City,2014,International Journal of Applied Engineering Research,V-9,I-22,P-7503-7507

3. Priyadarsini P., Bharthvajan R.,Role of emotional intelligence training programme in reducing the stress of the nurses,2014,International Journal of Applied Engineering Research,V-9,I-22,P-7411-7421

4. Kerinab Beenu G., Bharthvajan R.,Empirical analysis on the cosmetic buying behavior of young women in South India,2014,International Journal of Applied Engineering Research,V-9,I-22,P-7361-7366

5. Balakrishnan P., Bharthvajan R.,Whistling in the wind,2014,International Journal of Applied Engineering Research,V-9,I-22,P-7586-7593

6. Krishnan B., Peter M.,Health hazards of Indian Bpo employee-an alarming issue,2014,International Journal of Applied Engineering Research,V-9,I-22,P-7336-7341

7. Kerinab Beenu G.H., Peter M.,Role of insurance in economic development,2014,International Journal of Applied Engineering Research,V-9,I-22,P-7532-7539

8. Balakrishnan P., Peter M., Priyadarsini P.,Efficiency of safety measures for wellbeing of employees in manufacturing industry,2014,International Journal of Applied Engineering Research,V-9,I-22,P-7376-7382

9. Anbarasi M., Praveen Kumar S.,Online sales promotions of herbal products and its effectiveness towards tanisha.com,2019,Indian Journal of Public Health Research and Development,V-10,I-1,P-195-200

10. Anbarasi M., Praveen Kumar S.,Various online marketing and promotions strategies to improve the validation towards the organic products in the pharmaceutical sectors,2019,Indian Journal of Public Health Research and Development,V-10,I-1,P-263-269

11. Loganathan R., Praveen Kumar S.,Grievance handling a key factor for solving issues of employees in an organization,2014,International Journal of Applied Engineering Research,V-9,I-22,P-7483-7491

12. Loganathan R., Praveen Kumar S.,Study on preference of private label brands in super and Hypermarkets, 2014,International Journal of Applied Engineering Research,V-9,I-22,P-7327-7335

13. Smitha M., Praveen Kumar S.,Understanding stress and its managementamong the nurses in Chennai city,2014,International Journal of Applied Engineering Research,V-9,I-22,P-7560-7565

14. Kerinab Beenu G.H., Praveen Kumar S.,A study on the investment behavior of Chennai investors in mutual fund schemes,2014,International Journal of Applied Engineering Research,V-9,I-22,P-7520-7525

15. Loganathan R., Praveen Kumar S.,Retention strategies key for organizational productivity,2014,International Journal of Applied Engineering Research,V-9,I-22,P-7443-7447

16. Pavithra J., Ganesan M., Brindha G.,State wise analysis of microfinance sector in India,2016,International Journal of Pharmacy and Technology,V-8,I-4,P-23417-23432

17. Pavithra J., Ganesan M.,A comparative study on microfinance in India and abroad,2016,International Journal of Applied Business and Economic Research,V-14,I-8,P-5471-5476

18. Pavithra J., Ganesan M.,A study on awareness and impact of micro-financial schemes,2016,International Journal of Applied Business and Economic Research,V-14,I-8,P-5449-5460

19. Senthilmurugan P., Pavithra J.,Consumer preference towards organised retailing with reference to Big Bazaar,2014,International Journal of Applied Engineering Research,V-9,I-22,P-7469-7475

20. Senthilmurugan P., Pavithra J.,Implication of social media marketing in growing healthcare industry,2014,International Journal of Applied Engineering Research,V-9,I-22,P-7448-7456

21. Loganathan R., Pavithra J.,Consumer perception towards private labe brand over other brands in super markets and hypermarkets,2014,International Journal of Applied Engineering Research,V-9,I-22,P-7355-7360

22. Kerinab Beenu G., Pavithra J.,Tradeâ€"off between liquidity and profitability in logistics industry,2014,International Journal of Applied Engineering Research,V-9,I-22,P-7398-7401

23. Kerinab Beenu G., Pavithra J.,A study on the prospective consumerâ€ $\mathrm{TM}_{\mathrm{S}}$ perception towards utility cars in Chennai city,2014,International Journal of Applied Engineering Research,V-9,I-22,P-7526-7531

24. Pavithra J., Dilli Babu P., Ambuli T.V.,A study on budgetary control at Maruti Service Masters, Chennai,2014,International Journal of Applied Business and Economic Research,V-12,I-2,P-151-161

25. Pavithra J., Dilli Babu P., Ambuli T.V.,A study on customer satisfaction of retro Garments Pvt Ltd, Chennai,2014,International Journal of Applied Business and Economic Research,V-12,I-2,P-381-391

26. Kerinab Beenu G.H., Pavithra J., Senthilmurugan P.,A study on the influence of promotional activities for TATA ARIA among consumers in Chennai,2014,International Journal of Applied Engineering Research,V-9,I-22,P-7572-7578
27. Vijayaragavan S.P.,An investigative expert that's general FBG sensors,International Journal of Mechanical Engineering and Technology,V-8,I-8,PP-1500-1505,Y-2017

28. Vijayaragavan S.P.,Equalization routing protocol for Wi-Fi senso strategy,International Journal of Mechanical Engineering and Technology,V-8,I-8,PP-1662-1666,Y-2017

29. Karthik B., Kiran Kumar T.V.U., Vijayaragavan P., Bharath Kumaran E.,Design of a digital PLL using 0.35 $\hat{\mathrm{I}}^{1} / 4 \mathrm{~m}$ CMOS technology,Middle East Journal of Scientific Research,V-18,I-12,PP-1803-1806,Y-2013

30. Kanniga E., Selvaramarathnam K., Sundararajan M.,Kandigital bike operating system,Middle - East Journal of Scientific Research,V

31. Jasmin M., Vigneshwaran T., Beulah Hemalatha S.,Design of power aware on chip embedded memory based FSM encoding in FPGA,International Journal of Applied Engineering Research,V-10,I-2,PP-4487-4496,Y-2015

32. Jasmin M.,Optimization techniques for low power VLSI circuits,Middle East Journal of Scientific Research,V-20,I-9,PP-1082-1087,Y-2014

33. Jasmin M., Vigneswaran T.,Fuzzy controller for error control of on - Chip communication,2017 International Conference on Algorithms, Methodology, Models and Applications in Emerging Technologies, ICAMMAET 2017,V-2017-January,I-,PP-1-5,Y-2017

\section{AUTHORS PROFILE}

Magdalene Peter,Assistant Professor ,Department of MBA, Bharath Institute of Higher Education and Research, Tamilnadu, India

Dr.S.Fabiyola Kavitha, Associate Professor Department of MBA, Bharath Institute of Higher Education and Research, Tamilnadu, India 